\title{
SENTIDOS DO DEMONÍACO EM JOSÉ DE ALENCAR
}

\author{
Sandra Guardini Teixeira Vasconcelos \\ Universidade de São Paulo
}

\section{Resumo}

O artigo explora algumas apropriações do gótico no Brasil, focando dois romances de José de Alencar nos quais se apreende um aproveitamento de algumas de suas convenções, em especial aquelas que ajudam a representar a vida rural brasileira como uma experiência marcada pela violência e pelo excesso. Indaga, a partir disso, os sentidos dessa apropriação, sugerindo que ela diz muito sobre o processo de formação da nação brasileira.

Palavras-chave: gótico inglês, Walter Scott, José de Alencar, $O$ Tronco do Ipê, Til.

\section{MEANINGS OF THE DEMONIC IN JOSÉ DE ALENCAR}

\begin{abstract}
The article explores some appropriations of the Gothic in Brazil, focusing on two novels by José de Alencar which borrow some of its conventions, especially those useful to the representation of Brazilian rural life as an experience characterized by violence and excess. It enquires into the meanings of this appropriation,
\end{abstract}

\begin{tabular}{|l|l|l|l|l|}
\hline Ilha do Desterro & Florianópolis & $n^{\circ} 62$ & p. 271-292 & jan/jun 2012 \\
\hline
\end{tabular}


suggesting that it has a lot to say about the process of nation-building in Brazil.

Keywords: English Gothic, Walter Scott, José de Alencar, $O$ Tronco do Ipê, Til.

Tradicionalmente celebrado pela crítica como o romancista da identidade nacional, visão que um ensaio como "Bênção Paterna" decerto ajudou a construir, José de Alencar pareceria ter desenhado uma imagem solar da nova nação brasileira, ao criar uma espécie de mito de fundação, forjado na união dos povos e na ideia da reconciliação, como parecem sugerir os desfechos de Iracema e O Guarani, por exemplo. Um olhar mais atento à sua obra, porém, não pode deixar de perceber os aspectos mais sombrios ou violentos do processo de constituição de nossa identidade, mesmo se, não poucas vezes, eles ocupem antes as margens que o centro de seus romances. ${ }^{1}$

Estimulado por suas leituras de juventude, esse fundador do romance brasileiro valeu-se de modelos estrangeiros para criar uma obra de prospecção dessa identidade, tendo se tornado conhecido seu testemunho de que Amanda e Oscar e Saint-Clair das Ilhas ${ }^{2}$ haviam lhe deixado marcas e de que um dos moldes para o romance que o teriam inspirado era "merencório, cheio de mistérios e pavores" (Alencar, "Como e Porque Sou Romancista" 136). ${ }^{3}$ Se as sugestões do romance gótico não se tornaram um veio fecundo ou predominante em sua produção, nem por isso é impossível encontrar rastros de sua presença na obra madura do romancista, como é o caso de seus romances ditos regionalistas. Nesse artigo, detenho-me sobre $O$ Tronco do Ipê e Til, assim como comento brevemente O Guarani e As Minas de Prata para interrogar os sentidos dessa apropriação.

Pode parecer um contrassenso sugerir a existência de um gótico brasileiro, em contexto tão alheio e distante de seu local de origem. 
Entretanto, ao longo desses últimos 200 anos, essa modalidade literária teve presença contínua na história literária e cultural (cf. Duncan), tendo assumido uma pluralidade de significados e abarcado uma variedade de manifestações nos campos da narrativa, da arte, da arquitetura e do cinema. Não importa como e quando tenha sido usado, o termo sempre esteve associado com paranoia, barbarismo e tabu e com o questionamento da noção de "real" (cf. Punter), enquanto incorporava outras modalidades e gêneros para interpelar o sentido de "verdade".

Apesar dessa história contínua, porém, o gótico foi uma forma literária que surgiu e estava enraizada em um tempo e lugar muito específicos - a Grã-Bretanha de finais do século XVIII e inícios do XIX - e o que ela veio a significar é, em grande parte, resultado de um construto crítico, sob o qual se abrigou e se abriga uma diversidade de caminhos e soluções que estão longe de constituir um "movimento" ou uma adesão deliberada a um gênero unificado, ${ }^{4}$ ainda que, na origem, alguns de seus primeiros praticantes tenham se dedicado a examiná-lo ou a explicá-lo, como se pode ler nos dois prefácios a The Castle of Otranto de Horace Walpole, no artigo póstumo de Ann Radcliffe para o New Monthly Magazine (cit. in Duncan 261) e no ensaio "Essay on Romance" de Sir Walter Scott, por exemplo. ${ }^{5}$ Heterogêneo, instável, o Gothic romance (a partir de agora sempre traduzido como romanesco gótico), tendo se desenvolvido como a outra face do mundo claro e racional do Iluminismo, acabou por se consolidar como o que Chris Baldick descreveu como "o nome de um canto sinistro da imaginação ocidental moderna" (cit. in Watt 2) e constituir "a cultura do Gótico" (Duncan 20). Já desde sua primeira manifestação, propôs-se como um gênero híbrido, mistura do antigo e do moderno (cf. Walpole), de objetivo e subjetivo, de realismo e irrealismo, racionalidade e imaginação, história e ficção. 
A heterogeneidade, no entanto, não impediu o estabelecimento de alguns traços reconhecidamente góticos, topoi quase sempre associados a essa modalidade literária que de forma rotineira pôs em cena a ação do sobrenatural, um herói expropriado ou uma heroína perseguida e em apuros e cenários medievais (castelos, abadias, masmorras, ruínas) para tratar de um "contra-mundo sombriamente imaginado, que circunda as regiões menos confessas da psique, da família e da sociedade" (Botting 12). Foi nesse território fronteiriço que prosperaram os vários momentos góticos desde a ascensão do romanesco gótico em uma época marcada por importantes transformações no plano político e econômico e que assistiu ao florescimento da sociedade burguesa e industrial que iria conformar o mundo moderno.

Entre 1764 (com Hugh Walpole) e 1820 (com Charles Maturin), foram produzidos os textos chave do Gótico britânico e assentados os princípios estéticos e narrativos que possibilitariam os desdobramentos, transmutações e adaptações que essa modalidade literária viria a sofrer no processo de acolher, no seu interior, as inquietações culturais próprias de outros tempos e lugares. Literatura do excesso, que na origem se configurou como "crítica extravagante da razão iluminista" e "inconsciente político de uma sociedade de classe média" (Eagleton 19), o gótico pôde vicejar e se expandir em contextos muito diversos, assumindo formas específicas como o roman noir e o roman frénetique na França ou o Schauerroman na Alemanha. Do mesmo modo, atravessou outras fronteiras e cruzou os mares, aclimatando-se nos Estados Unidos da América, com Edgar Allan Poe e Nathaniel Hawthorne, ou aportando em terras brasileiras, antes mesmo que o romance brasileiro estivesse consolidado. De uma Inglaterra finissecular nos chegaram ecos dessa modalidade de ficção, que tematiza os sonhos aterradores que assombram o homem 
e que Maggie Kilgour definiu como "uma visão de pesadelo de um mundo moderno, feito de indivíduos separados, que se dissolveu em relações predatórias e demoníacas que não podem ser reconciliadas numa ordem social saudável” (12).

Se pelo menos desde a década de 1820 os romances ingleses começam a frequentar com irrefutável assiduidade as páginas do Jornal do Comércio e do Diário do Rio de Janeiro, em anúncios de livreiros e livrarias que passavam a se estabelecer cada vez em maior número na capital do Império do Brasil, não escapam ao olhar mais atento a profusão de títulos e a disponibilidade, entre eles, dos romances góticos responsáveis pela grande popularidade de seus autores do outro lado do Atlântico havia apenas alguns anos. É nesses jornais que encontramos as primeiras referências à presença, na cidade, das obras de fundadores do gênero, como Ann Radcliffe (Diário do Rio de Janeiro, 1825) e, possivelmente, ${ }^{6}$ Matthew Lewis (Jornal do Comércio, 1828), ou de Amanda e Oscar (Diário do Rio de Janeiro, 1824) e Saint-Clair das Ilhas (Diário do Rio de Janeiro, 1825), os romances que fariam as delícias do jovem Alencar. A permanência desses nomes e títulos nos anúncios de periódicos, assim como nos catálogos das bibliotecas e gabinetes de leitura que também passaram a fazer parte da paisagem e dos equipamentos culturais do Rio de Janeiro, permite supor a existência de um público leitor para esses romances e um interesse duradouro pelas aventuras e atribulações de personagens envolvidas em tramas de mistério, suspense, vingança, poder despótico, tirania e horror.

Sem ruínas medievais nem um passado feudal, sem as relíquias e objetos que fizeram a fama do romance gótico e foram incorporados às suas convenções, o cenário brasileiro pareceria um espaço improvável e inverossímil para produzir esse tipo de ficção. No entanto, motivos góticos surgem pela primeira vez na ficção brasileira, salvo engano, em um conto anônimo publicado em 4 partes no Jornal do 
Comércio, entre 23 e 27 de fevereiro de 1839. "A Ressurreição de Amor (Crônica Rio-grandense)" toma emprestado, numa atmosfera em que predominam o mistério e o horror, algumas dessas convenções, ao narrar a história de seu perturbado protagonista Francisco, que viola a sepultura de sua amada apenas para descobrir que ela ainda vive, na melhor tradição do gênero. Em linguagem hiperbólica, o narrador não perde a oportunidade de louvar as belezas naturais de sua província, enquanto conta uma história de horror e morte. Valendo-se de longas descrições da paisagem natural, o autor anônimo tenta estabelecer alguma relação causal entre espaço e enredo, mas produz, na verdade, uma fratura formal entre o pano de fundo brasileiro e a narrativa de amor e loucura, à maneira do melodrama europeu - uma narrativa de amores frustrados pelas diferenças sociais entre o aristocrático Francisco, irmão do governador, e Amália, uma jovem rica porém plebeia.

Haveria que lembrar, ainda, o caso de Álvares de Azevedo, cujo Noite na Taverna, publicado postumamente em 1855, teve em Lorde Byron e E.T.A. Hoffmann autores modelares e no qual apreendemos fortes elementos góticos, revelados no gosto pelo satanismo e pelo macabro, facilmente filiados à tradição inaugurada por Matthew Lewis, ele próprio uma espécie de outsider entre os escritores góticos canônicos, pelo recurso às fontes alemãs, pela licenciosidade, pela aposta no repulsivo e pela recusa da linguagem do sentimento, característica do gótico "feminino" Aqui, não estamos no terreno do romance radcliffiano, com sua contemplação da beleza natural que evoca o sublime, seu sobrenatural explicado, e seus enredos que remetem ao romance sentimental de corte richardsoniano. Ao contrário, o que voga é a ironia, a transgressão sistemática, a ousadia e a ruptura com quaisquer noções de providência e justiça, o que valeu a Lewis a condenação da crítica e uma recepção bastante acidentada 
na Inglaterra. Foi nessa vertente demoníaca do gótico que embarcou Álvares de Azevedo, o que permite situar Noite na Taverna "como herdeira bastarda do gótico inglês e das obras sombrias de Hoffmann e dos frenéticos franceses, com pitadas de Sade e dos melodramas, além, é claro, da ligação com Byron e de seu herói com os vilões góticos" (Oliveira 162-163). Reconhece-se, nesse aproveitamento de diversas fontes e sugestões, o que Robert Kiely descreveu como traço característico da ficção romântica, o "método colcha de retalhos", que justapõe "propósitos estéticos, estilos literários, padrões narrativos e temas de tipos totalmente diferentes" (3).

Se o jovem José de Alencar também teve sua fase byroniana, conforme anota M. Cavalcanti Proença $(O C 1,118),{ }^{7}$ foi, na verdade, o "honroso cargo de ledor" de novelas e romances que ocupou nos serões domésticos que teria sido responsável por imprimir "em [seu] espírito a tendência para essa forma literária que é entre todas a de [sua] predileção" (Alencar, "Como e Porque Sou Romancista" 133). À "diminuta livraria romântica formada ao gosto do tempo" (131) a que tivera acesso quando menino, Alencar revela em sua autobiografia literária, vieram se somar os franceses Balzac, Chateaubriand, Hugo e Vigny e, para o que me interessa nesse artigo, as escritoras inglesas, Sir Walter Scott e o Capitão Frederick Marryat, dos quais Alencar destaca os romances marítimos e os combates heroicos. Se aqui um Alencar quase no final da vida faz um retrospecto de sua carreira literária, suas escolhas e seus autores de eleição já aparecem desde cedo, na polêmica contida nas "Cartas sobre A Confederação dos Tamoios" (1856), a primeira exposição sistemática de suas ideias e princípios estéticos, publicada sob o pseudônimo de IG. A adoção e defesa do romance, em lugar da epopeia, como gênero ideal para tratar das peculiaridades brasileiras logo encontrariam concretização em $O$ Guarani, que saiu à mesma época sob a forma de folhe- 
tim no Diário do Rio de Janeiro e depois como livro, em janeiro de 1857. Nessa espécie de programa, que parece anunciar o romancista que ele logo viria a ser, desenham-se alguns caminhos que Alencar iria trilhar, assim como suas afinidades eletivas, entre as quais surge Scott, lembrado como o romancista de língua inglesa capaz de fazer do poema de Magalhães um romance e dar-lhe "encanto" e interesse" (Alencar, "Cartas" 893). Nada nas "Cartas" permite antever a importância do molde "merencório, cheio de mistérios e pavores" que o escritor alegaria, anos mais tarde, ter deixado marcas no seu espírito. Nem, à primeira vista, seria possível associar o fundador do romance histórico, ou o próprio Alencar, à linhagem de escritores góticos ou às romancistas Regina Maria Roche e Elizabeth Helme que lhes foram contemporâneas.

Entretanto, na intrincada rede de trocas, empréstimos, apropriações e contribuições inovadoras que sempre caracterizou a história do gênero romance, pode-se não apenas traçar linhas e pontos de contato entre essas diferentes fontes "inglesas" de Alencar, mas também sugerir que o denominador comum entre todas elas é o romanesco (romance, em inglês), a modalidade literária que o gótico recuperou e restituiu a um lugar de visibilidade e proeminência na Inglaterra de finais do século XVIII e que vai igualmente figurar no historical romance de Sir Walter Scott. Scott foi leitor de Ann Radcliffe, sobre quem fez um longo e detalhado estudo introdutório para a Ballantyne's Novelist's Library em 1824, e amigo de Charles Maturin, de quem resenhou o primeiro romance, Fatal Revenge (1807), para o Quarterly Review e com quem manteve correspondência e trocou ideias sobre as opções literárias do pároco irlandês. ${ }^{8}$ Victor Sage argumenta que, ao aconselhar que seu interlocutor matizasse "o desdobramento hiperbólico" do romanesco radcliffiano, Scott vocalizava uma crítica ao gótico de Maturin, derivado diretamente de Radcliffe e Lewis, e já sinalizava a 
direção que iria tomar seu "historical romance racionalizado e modernizado" (82). Voltarei a Scott mais adiante.

Em princípio, em um projeto literário, explicitado retrospectivamente em seu "Bênção Paterna" (1872), que tinha visado a narrar a história da formação do povo e da nação brasileira, nos romances indianistas e históricos, a mapear os espaços, tipos e paisagens regionais, e a traçar a "fisionomia da sociedade fluminense", nos romances urbanos, pareceria não haver lugar para os ornamentos convencionais do gótico. Contudo, a obra preponderantemente luminosa e solar ${ }^{9}$ do autor de Iracema se tinge de sombras de quando em quando e incorpora algumas convenções góticas, numa apropriação cujo sentido é preciso interrogar. Assim, à imagem de um Brasil "filho do sol" (Alencar, "Cartas" 869), onde o processo de construção da identidade e da nacionalidade pareceria ter se dado sem conflitos, se acrescenta uma visão mais problemática e complexa de uma sociedade na qual o encontro supostamente harmonioso das raças oculta uma história de violência, opressão e trauma social, aspectos que o romanesco canônico enfrenta e expõe no centro de seus enredos e que Alencar muitas vezes desloca para as margens ou bordas de sua ficção.

Há um desejo de realidade no romance de Alencar. Sem dúvida, o propósito de perscrutar "a gestação lenta do povo americano" e "tirar a fotografia desta sociedade" (Alencar, "Bênção Paterna" 697) demandaria do escritor não apenas o recurso à crônica histórica, de onde extraiu os fatos e personagens históricos que entremeia aos elementos ficcionais, ${ }^{10}$ mas ainda a aderência ao conteúdo de verdade que possibilitaria ao leitor reconhecer sua experiência do país e da sociedade brasileira nas histórias narradas. A concepção de romance de Alencar, no entanto, já é emblemática de uma ambiguidade, ou melhor, da convivência de duas modalidades que emprestam um caráter híbrido à sua produção romanesca. Ao definir o romance como 
"poema da vida real" (Alencar, "Como e Porque" 139), fica patente a dupla orientação que presidiu a armação de seus enredos, em que o histórico e o ficcional, o imaginário e o real irão se entrelaçar quase que de modo programático. Não foi outro, embora com variações, o caminho de Walter Scott, que também, de acordo com um artigo precoce na Blackwood's Edinburgh Magazine, operou a síntese entre história e romanesco, de modo a prover "a verdade da história sem a monotonia - o interesse do romanesco sem sua irrealidade" (346). ${ }^{11}$ Nem Scott nem Alencar, convém advertir, investiram no potencial que tinha o gótico para o escapismo e para as manobras de evasão, tão característicos de sua forma canônica.

Onde se encontraria, então, o elemento gótico na obra de Alencar? Já sugeri acima que ele é sempre empurrado para as margens da narrativa, o que significa que nunca ocupa um lugar central na trama, nem serve para qualificar heróis ou definir o clima predominante das histórias. Se o recurso ao romanesco é inegável em uma obra como O Guarani, que faz de seu herói um ser dotado de uma excepcional capacidade de ação que o situa acima dos homens comuns, ou em As Minas de Prata (1865-1866), no qual uma "imaginação feérica" ${ }^{12}$ cria um enredo centrado em uma busca que acumula aventuras num ritmo frenético e folhetinesco, a crônica histórica e o propósito de sondar as origens da nacionalidade delimitam, por assim dizer, os excessos que se costumam atribuir ao gênero. Em ambos os casos, embora marginal, a contribuição do gótico se pode apreender na caracterização e na atuação de duas personagens que acumulam traços dos vilões góticos de extração radcliffiana. Daniel S. de Sá já sugeriu as conexões que se podem estabelecer entre o condottiere Loredano e "seus possíveis modelos góticos", Schedoni (The Italian, de Ann Radcliffe) e Ambrosio (The Monk, de Matthew Lewis) ${ }^{13}$ (cf. Sá). 
A figura do Padre Gusmão de Molina, em As Minas de Prata, se filia a essa mesma tradição. $O$ jesuíta espanhol de "aparência enganadora" e pupilas negras que refletem o "fogo vulcânico" será o responsável pelas grandes maquinações e vilanias que envolvem a busca do roteiro das minas de prata e a fortuna do jovem Estácio Álvares Correia. Entre os vaivéns da trama, cheia de lances folhetinescos, assoma a presença demoníaca de Molina, visitador do Santo Ofício na cidade de Salvador e figura de surpreendentes ardis e astúcia, cuja cobiça e ambição desmedidas remetem igualmente a Schedoni, também ele homem da Inquisição e instrumento de perseguição implacável a Vivaldi, o protagonista de Radcliffe. Assim como em The Italian, segredos e disfarces são centrais à intriga e ajudam a criar uma atmosfera soturna por onde se insinua uma visão menos positiva e harmoniosa do processo de formação da nação brasileira. Nosso passado, sugere Alencar agora pelo prisma desses empréstimos estrangeiros, teve seu considerável tanto de fraude e violência.

Ainda que deslocados no tempo e no espaço e diversos na concepção e escopo, O Tronco do Ipê (1871) e Til (1872) também incorporam traços convencionalmente góticos a seus retratos dos usos e costumes do mundo rural na região cafeeira do Rio de Janeiro e no interior paulista no século XIX, respectivamente. Seu viés realista, que deriva do intento de representação da vida cotidiana e das relações humanas em duas grandes propriedades agrícolas, se mescla com alguns clichês da maquinaria gótica, sobretudo aqueles que levam o leitor a acreditar na natureza sobrenatural dos acontecimentos, mais tarde devidamente explicados ao leitor. Esse recurso ao esclarecimento racional e tardio dos fatos produz certo retardamento da ação que, com frequência se suspende, adiando sua resolução. No intervalo entre o acontecimento e a explicação, no entanto, fica no ar a sugestão de um ambiente doméstico tingido pelo sinistro, pelo 
que escapa da esfera da razão. Nesse espaço, entra toda espécie de desvarios, obsessões e monomanias. Estamos aqui no terreno do não familiar, do grotesco, das paixões exacerbadas.

Narrado em retrospecto por um narrador extradiegético, quando a fazenda de Nossa Senhora do Boqueirão já é só ruínas e abandono, $O$ Tronco do Ipê tem sua intriga situada entre 1850 e 1857 e relata o que aparenta ser uma história de usurpação, tendo no seu centro as famílias de Joaquim de Freitas, o Barão de Espera, e de José Figueira, herdeiro presuntivo das terras, já falecido. Seus filhos, respectivamente Alice e Mário, são os protagonistas dessa narrativa que tenta trançar amor e mistério e mobiliza alguns dos lugares-comuns do romance sentimental inglês, de que Ann Radcliffe e Regina Maria Roche também foram tributárias, e do romance gótico, adaptando-os à realidade local. Assim, se as diferenças de posição social e de fortuna entre Mário e Alice fazem parte do repertório novelístico desde Samuel Richardson, alguns dos ornamentos góticos característicos sofrerão uma aclimatação ao universo no qual serão inscritos. Como estamos no interior do Brasil, distantes das modernidades a que certamente tinham acesso os habitantes da capital do Império, há espaço para as crendices e superstições locais, que o narrador logo se apressa em referir. Uma fazenda mal-assombrada, histórias de almas de outro mundo, um bruxo pactário (pai Benedito), feitiçaria, poderes sobrenaturais, vozes, aparições, uma legião de fantasmas são todos eles elementos que irão compor o enredo, para serem, um a um, desmistificados pela razão. São, entretanto, sistematicamente convocados para criar o clima de mistério e pavor que ronda o episódio da morte de José Figueira no Boqueirão.

Até que se revelem as verdadeiras causas e circunstâncias dessa morte, pesará sobre o Barão de Espera a suspeita de Mário de que seu pai havia sido vítima de uma usurpação e de assassinato. Pobre e 
destituído, Mário vive de favor com sua mãe na fazenda e é um rapaz revoltado e misantropo. Muitas reviravoltas serão necessárias para que a verdade venha à tona e a narrativa caminhe para o final feliz. Até lá, o leitor experimentará os chamados "teasers", os suspenses, os cortes narrativos, as coincidências, os segredos, todos eles truques góticos que proliferam nesse romance descosido, que junta, além do enredo sentimental e de mistério, "histórias da carocha" (Alencar 655), auto de Natal, jongo e comédia, essa personificada no glutão e servil Senhor Domingos Pais, agregado da fazenda. Trata-se aqui de uma colagem de gêneros, ou do "método colcha de retalhos" a que se refere Kiely. Sobretudo, nesse ambiente tipicamente brasileiro, no qual encontramos figuras frequentes na ficção nacional como os agregados e os escravos, transcorre o enredo tipicamente europeu dos amores atribulados da moça rica e do rapaz pobre, separados pelo dinheiro e pela classe social, e a quem a verdade dos fatos restituirá a possibilidade de um final feliz.

Em outra fazenda, a das Palmas, dessa vez às margens do Rio Piracicaba, a trama amorosa reúne os gêmeos Afonso e Linda, filhos do proprietário rural Luís Galvão, e Miguel e Berta, os irmãos de criação pobres que lhes servem de contraponto. Emoldurado pela atmosfera doméstica e plácida que abre e fecha o romance, o miolo do entrecho encena uma série quase inverossímil de eventos funestos e violentos, que incluem um incêndio, corpos calcinados, um ataque de uma vara de porcos bravios, perseguições e tramoias. Tudo é excessivo nesse romance, com suas personagens presas de ódios implacáveis, de terrores supersticiosos e alucinações, e extravagâncias de toda espécie. Embora se queira fazer crer ao leitor que se trata um lugar mal-assombrado, não há nada de sobrenatural na Fazenda das Palmas. Se ali rondam fantasmas, são os fantasmas do passado, que movem as ações dos homens do presente. Dessa 
forma, a intriga amorosa, tão característica e central em outros romances de Alencar, fica soterrada por uma história de vingança, na qual o acerto de contas com a violação e assassinato de uma mulher (Besita, mãe de Berta) mobiliza Jão Fera, o bugre capaz de atrocidades terríveis. O segredo do nascimento de Berta, o seu reconhecimento, o testamento que surge ao final, palavras obscuras, meias verdades, são todos clichês do gênero, que a trama explora ao máximo. Talvez o índice mais evidente dos exageros desse romance esteja concentrado no seu desfecho, em que Berta escolhe não acompanhar sua nova família, mas sim, "flor da caridade, alma soror", "perfumar os abismos da miséria" e ficar nas Palmas com "o idiota, a louca e o facínora remido" (Alencar 1010).

Avultam, em detrimento de uma maior sondagem psicológica das personagens, o enredo, que empilha acontecimento sobre acontecimento, e a voz narrativa, que chama para si a responsabilidade de explicar, julgar, avaliar, num tipo de intrusão que nega a seus caracteres a prerrogativa ou oportunidade de revelarem suas próprias verdades diretamente ao leitor. Pode-se dizer que se aprofundam aqui as "claudicações" que Augusto Meyer havia percebido em O Gaúcho (OC III, 413), o que talvez venha a explicar por que Pinheiro Chagas considerou Til uma "incrível profusão de disparates" (cit. Araripe Júnior, OC III, 1328) ou por que o próprio Araripe Júnior tenha visto nele "uma exibição de monstruosidades", "uma espécie de sala de hospício de alienados" (OC III, 815-816). Nesse sentido, ele é bastante diverso do restante da obra de Alencar, porque, sempre numa dicção enfática, sobrepõe o ínfero, o baixo, o grotesco, ao registro elevado e ao estilo poético que fizeram a fama de seu autor.

Restaria indagar por que, nesses dois romances regionalistas, Alencar recorreu de modo tão insistente ao repertório gótico ${ }^{14}$ para conformar aspectos daquilo que Cavalcanti Proença denominou de 
"o grande painel da vida brasileira" (OC III, 1015). Estamos aqui no território dos romances que não constituem propriamente o cânone alencariano e ocupam um lugar menos proeminente na obra completa do escritor. São romances que, exatamente por se situarem no interior do país, em zonas mais atrasadas em relação à capital, abrigam personagens talvez mais suscetíveis às superstições, às crendices, às lendas. Distantes do mundo da corte, com suas regras de etiqueta, seus padrões de sociabilidade e comportamentos prescritos, as regiões retratadas em $O$ Tronco do Ipê e Til apresentam sua quota de selvageria e rusticidade, abrindo espaço para a representação menos controlada das relações de violência que pautaram os modos de vida no Brasil oitocentista. Alencar, desse modo, nos põe diante da inversão completa do cavalheirismo medieval, por exemplo, de Peri e de Estácio (Araripe Júnior fala em degenerescência desse ideal), assim como aciona todo o arsenal da tópica gótica - a revelação postergada de um mistério narrativo central, a evocação do temor provocado por ameaças de violência ou aprisionamento, o uso do sinistro, $o$ diferimento da ação - para trazer à tona a dimensão demoníaca e infernal da formação da sociedade brasileira.

Poucas cenas são tão indicativas dos descompassos que nos constituíram como a da festa de São João na Fazenda das Palmas, que expõe de modo incontornável as diferenças e impasses desse mundo social. Em três espaços contíguos, convivem a "boa sociedade" dos detentores do poder e do dinheiro, os velhos costumes do campo, e a escravaria da senzala. Escreve Alencar:

A festa da sala é cidadã. Damas e cavalheiros tiram sortes, cerimoniosamente sentados em volta de uma mesa; ou dançam quadrilhas e valsas figuradas; enquanto pelos cantos os velhos fazendeiros falam a respeito das carpas, da nova flor do café, e das geadas, seu constante pesadelo. No terreiro folgam os rapazes 
que acham mais graça na função campestre, e em vez de consultar o livro do fado, confiam nos oráculos da fogueira, saltando-a de corrida, e passando nela o ovo, que há de ficar ao relento à hora fatídica da meia-noite. (Alencar 964)

Em torno da fogueira, já esbarrondada pelo chão, que ela cobriu de brasido e cinzas, dançam os pretos o samba com um frenesi que toca o delírio. Não se descreve, nem se imagina esse desesperado saracoteio. No qual todo o corpo estremece, pula, sacode, gira, bamboleia, como se quisesse desgrudar-se.

Tudo salta, até os crioulinhos que esperneiam no cangote das mães, ou se enrolam nas saias das raparigas. Os mais taludos viram cambalhotas e pincham à guisa de sapos em roda do terreiro. Um desses corta jaca no espinhaço do pai, negro fornido, que não sabendo mais como desconjuntar-se, atirou consigo ao chão e começou a rabanar como um peixe seco.

No furor causado pelo remexido infernal, alguns negros arremetem contra a fogueira e sapateiam em cima do borralho ardente, a escorrer do braseiro. (Alencar 975-976)

O contraste entre os grupos não poderia ser mais flagrante. As comportadas danças e conversas de salão, que poderíamos encontrar em qualquer romance europeu do século XIX, de um lado, parecem fazer sobressair ainda mais o samba dos pretos, descontrolado, desregrado, de outro. A escolha do vocabulário, como de costume, também não deixa dúvidas. $\mathrm{O}$ animalesco, o rebaixado e o ínfero são sempre prerrogativa dos estrangeiros (caso de Loredano e Molina) e dos negros e bugres, como Jão Fera, ${ }^{15}$ e destoam sensivelmente do alto grau de idealização que recobre a caracterização das personagens principais e da linguagem usada para descrevê-los e referi-los.

Poderíamos concluir, a essa altura, que a apropriação por Alencar de algumas das convenções góticas se deveu muito mais ao paradigma radcliffiano que, de alguma forma, lhe chegou indiretamente 
pelos romances "cheios de mistérios e pavores" que leu na juventude, como foi o caso de Amanda e Oscar, quase tão famoso em sua época quanto The Mysteries of Udolpho e tributário da obra daquela que foi celebrada como "the Shakespeare of romance writers". ${ }^{16}$ Isto posto, podemos agora voltar a Scott, uma vez que podem não ter sido desprezíveis as sugestões que o escritor brasileiro teria recebido também do escocês, admitidamente um de seus autores de predileção.

Scott, como sabemos, tornou-se uma referência no século XIX como o fundador do romance histórico, e seus Waverley Novels marcaram época como prospecções do passado da Escócia e das consequências humanas das mudanças que se operaram durante sua turbulenta história. Apesar de Scott ter sido "louvado por quebrar o encanto do romanesco e, em lugar disso, introduzir seus leitores no espaço comunal da história e da vida pública" (Watt 153), motivos góticos não estiveram de todo ausentes em sua produção ficcional. Northrop Frye já havia chamado atenção para o recurso a certas técnicas formulaicas, como o nascimento misterioso do herói, as sociedades secretas ou proscritas, as profecias, o contraste entre as heroínas loira e morena, que fascinaram o crítico na leitura de Guy Mannering (1815) (Frye 5), e notara como os Waverley Novels "marcam a absorção do deslocamento realista no interior do próprio romanesco" (41), produzindo uma "associação frequente do romanesco com o histórico" (176). É nesse espaço menos comprometido com a veracidade histórica e mais aberto à fantasia e à imaginação que se apreende um uso extensivo dos dispositivos que relacionamos com o gótico. Sobre a síntese operada por Scott entre história e romanesco, Watt observa ainda:

Em obras como Ivanhoe, The Antiquary, e The Bride of Lammermoor, por exemplo, Scott subsumiu as convenções góticas em 
um travejamento histórico, ou estabeleceu uma oposição entre romanesco e vida real a fim de relegar o romanesco gótico ao status de anacronismo ficcional. Contudo, nos mesmos romances, Scott também qualificou o rigor com o qual assimilou ou digeriu a matéria prima romanesca, e - como em The Antiquary e The Bride of Lammermoor - complicou o tom e a identidade de sua obra ao replicar certos tropos e motivos góticos de um modo aparentemente fiel. (144)

E Ivanhoe, "o romance mais popular de um dos mais amados autores britânicos de todo o século XIX", conforme lembra Duncan (“Introduction” viii), será emblemático dessa opção, pois "realiza a virada fatal na carreira de Scott de um realismo histórico outrora influente (nos romances sobre a formação da Escócia moderna) para um medievalismo de ouropel e pretencioso" (viii-ix). A fama e o impacto de Ivanhoe atravessaram fronteiras e, embora sua leitura por parte de Alencar só possa ficar no terreno da mera suposição, a presença desse romance (e de outros de Scott) no Rio de Janeiro ao longo de todo o século XIX ${ }^{17}$ foi instrumental para tornar disponível e popularizar o repertório de elementos góticos que iremos encontrar nos romances alencarianos comentados acima, assim como para expor toda a complexa relação de Scott com seus próprios precursores, como Hugh Walpole, Ann Radcliffe e Matthew Lewis. Se flagramos, no caso brasileiro, uma tendência semelhante à "goticização" do romance rural e do cotidiano doméstico e prosaico, faltam a Alencar, no entanto, a ambivalência e o tratamento irônico que muitas vezes Scott dispensou a seus materiais e à tradição gótica que o antecedeu.

Com isso, encerro a sondagem desse gótico brasileiro, salientando que não pretendi aqui fazer o papel de um daqueles "caçadores de influências" de que fala Cavalcanti Proença (OC III, 1014), mas, antes, explorar os processos de circulação e apropriação de temas e pro- 
cedimentos, tão característicos de um gênero inter-nacional como o romance, assim como restabelecer e recuperar a rede de leituras que formaram um escritor tão central para a tradição brasileira como José de Alencar. Do mesmo modo, deixo sugerido que, para a formação do nosso sistema literário, também contribuíram essas obras inglesas gestadas em tempos e lugares tão distantes de nós.

\section{Notes}

1. Salvo engano, foi Roberto Schwarz, em Ao Vencedor as Batatas, o primeiro a chamar atenção para as bordas ou aspectos periféricos do romance alencariano e ressaltar as tensões presentes na obra do escritor. Antes dele, a crítica sempre privilegiou os temas da construção da nação e da identidade brasileiras como um processo harmônico e destituído de contradições. Mais recentemente, porém, verificou-se uma inflexão na fortuna crítica de Alencar, a qual tem se empenhado em uma leitura mais problematizada da obra desse que foi um dos mais importantes criadores do romance brasileiro.

2. Amanda e Oscar, ou história da família de Dunreath, de Regina Maria Roche (The Children of the Abbey. London: William Lane, 1796); Saint-Clair das Ilhas, ou os desterrados na ilha de Barra, de Elizabeth Helme (Saint-Clair of the Isles; or, The Outlaws of Barra. A Scottish Tradition. London: Longman and Rees, 1803).

3. Eis o trecho: "Um merencório, cheio de mistérios e pavores; esse, o recebera das novelas que tinha lido. Nele a cena começava nas ruínas de um castelo, amortalhadas pelo baço clarão da lua; ou nalguma capela gótica frouxamente esclarecida pela lâmpada, cuja luz esbatia-se na lousa de uma campa." Utilizo nesse artigo as Obras Completas do autor, que contêm ainda apreciações críticas por diversos estudiosos. As citações a esses estudos serão sempre localizadas daqui em diante pela abreviação $O C$ seguida do número do volume e página(s) em que se encontram.

4. Foi apenas na primeira metade do século XX que o gótico passou a ser tratado como um gênero unificado e isso ocorreu como um gesto crítico, em estudos como os de Edith Birkhead (The Tale of Terror, 1921), Eino Railo (The Haunted Castle, 1927), J.M.S. Tompkins (The Popular Novel in England, 1770-1800, 1932), Montague Summers (The Gothic 
Quest, 1938) e Devendra Varma (The Gothic Flame, 1957), primordialmente.

5. Ver Sir Walter Scott. Miscellaneous Prose Works, vol. 1, part 6. Edinburgh: Robert Cadell, 1841. Há ainda o ensaio "On the Supernatural in Fictitious Composition; and particularly on the Works of Ernest Theodore William Hoffmann", coligido em Ioan Williams. Sir Walter Scott on Novelists and Fiction. London: Routledge \& Kegan Paul, 1968, p. 312-353.

6. Como as informações nos anúncios são, na maior parte das vezes, incompletas e os títulos e nomes de autores são grafados erradamente, no caso de Lewis só podemos supor que se trate do autor de The Monk, já que não há dados mais precisos que possibilitem certezas.

7. Em "Como e Porque Sou Romancista", Alencar lembra: "Em 1845, voltou-me o prurido de escritor; mas esse ano foi consagrado à mania que então grassava de byronizar. Todo estudante de alguma imaginação queria ser um Byron, e tinha por destino inexorável copiar ou traduzir o bardo inglês" (141).

8. O contato de Walter Scott com os autores góticos incluiu ainda as resenhas que escreveu para periódicos, assim como as biografias críticas de Horace Walpole e Clara Reeve que preparou para a mesma Ballantyne's Novelist's Library.

9. Esse aspecto solar decorre, fundamentalmente, do tratamento que Alencar dá à natureza e paisagem brasileiras, sem prejuízo dos aspectos mais traumáticos e do tom mais soturno de que sua obra se reveste ao tematizar os processos de formação da nação brasileira.

10. Sobre o modo de incorporação da História no romance histórico alencariano, remeto o leitor ao meu artigo "Figurações do passado: o romance histórico em Walter Scott e José de Alencar”. Terceira Margem 18 (2008) : 15-37.

11. Anônimo. “The Historical Romance”. Blackwood's Edinburgh Magazine 58 (1845) : 341-356.

12. Brayner, Sonia. "José de Alencar e o Romance Histórico". O Estado de São Paulo (Suplemento Literário) 869, 24 de março de 1974.

13. Ann Radcliffe. The Italian, or The Confessional of the Black Penitents (1797); Matthew Lewis. The Monk (1796). 
14. O último momento gótico em Alencar é uma cena no romance Encarnação, segundo Eugênio Gomes decalcada em The Mysteries of Udolpho, de Ann Radcliffe. Diz o crítico: "A cena em que Emily desmaia, tomada de pânico, ao descerrar uma cortina que ocultava algo que lhe pareceu um espectro e não passava de uma figura de cera... Idêntica estupefação teve Amália, no romance de Alencar, quando surpreendeu a escultura da rival defunta, que supôs um cadáver, no primeiro momento" (OC I, 1219-1220).

15. Regionalistas, embora, O Gaúcho e O Sertanejo, talvez porque pretendam enaltecer dois tipos brasileiros e apostem na sua idealização, descartam o uso sistemático desses procedimentos.

16. Nathan Drake, Literary Hours; or, Sketches Critical, Narrative, and Poetical. 2a. ed., 2 vols. (1800), I: 359.

17. Praticamente o conjunto da obra de Scott passou a estar disponível em francês, em inglês e em português desde finais da década de 1830 .

\section{Referências}

Alencar, José de. Obra Completa. 4 vols. Rio de Janeiro: Editora José Aguilar, 1959.

Botting, Fred. “Gothic Darkly: Heterotopia, History, Culture.” A Companion to the Gothic. Ed. David Punter. Oxford: Blackwell, 2001. 3-14.

Duncan, Ian. Modern Romance and Transformations of the Novel. The Gothic, Scott, Dickens. Cambridge: Cambridge University Press, 2005.

Eagleton, Terry. “The Nature of Gothic." Figures of Dissent. London and New York: Verso, 2005. 17-23.

Frye, Northrop. The Secular Scripture. A study of the structure of romance. Cambridge, Mass.: Harvard University Press, 1978.

Gil, Fernando C. “O caráter pendular do herói brasileiro." Literatura e Sociedade 13 (2010.1) : 132-151.

Kelly, Gary. English Fiction of the Romantic Period, 1789-1830. London and New York: Longman, 1989.

Kiely, Robert. The Romantic Novel in England. Cambridge, Mass.: Harvard University Press, 1972. 
Kilgour, Maggie. The Rise of the Gothic Novel. London and New York: Routledge, 1995.

Martins, Eduardo Vieira. “A Imagem do Sertão em José de Alencar.” Dissertação de Mestrado. Universidade Estadual de Campinas, 1997.

Oliveira, Jefferson Donizetti de. "Um Sussurro nas Trevas. Uma revisão da recepção crítica e literária de Noite na Taverna de Álvares de Azevedo." Dissertação de Mestrado. Universidade de São Paulo. 2010.

Punter, David. "Introduction: The Ghost of a History." A Companion to the Gothic. Ed. David Punter. Oxford: Blackwell, 2001. viii-xiv.

. The Literature of Terror. A History of Gothic Fictions from 1765 to the present day. London and New York: Longman, 1996.

Sá, Daniel Serravalle de. Gótico Tropical. O sublime e o demoníaco em $O$ Guarani. Salvador: EDUFBA, 2010.

Sage, Victor. "Irish Gothic: C.R. Maturin and J.S. LeFanu." A Companion to the Gothic. Ed. David Punter. Oxford: Blackwell, 2001. 81-93.

Scott, Sir Walter. Ivanhoe. Ed. Ian Duncan. Oxford: Oxford University Press, 1996.

. On Novelists and Fiction. Ed. Ioan Williams. London: Routledge \& Kegan Paul, 1968.

Vasconcelos, Sandra Guardini T. "Figurações do passado: o romance histórico em Walter Scott e José de Alencar”. Terceira Margem 18 (2008): 15-37.

Watt, James. Contesting the Gothic. Fiction, Genre and Cultural Conflict, 1764-1832. Cambridge: Cambridge University Press, 1999.

[Recebido em 07/02/2012. Aprovado em 23/04/2012] 